\title{
Analytical Concept of Fungicide Resistance: A Review
}

\author{
Rajat Sharma* \\ Department of Plant Pathology, Dr Y. S. Parmar University of Horticulture and Forestry, \\ Nauni, Solan- 173230 H.P., India \\ *Corresponding author
}

A B S T R A C T

\begin{tabular}{l} 
Ke y w o r d s \\
Fungicide \\
Resistance, \\
Phytotoxicity, \\
Fungicide Action, \\
Resistance \\
Emergence \\
Article Info \\
\hline $\begin{array}{l}\text { Accepted: } \\
15 \text { November } 2019 \\
\text { Available Online: } \\
10 \text { December } 2019\end{array}$ \\
\hline
\end{tabular}

The foundation of sheltered and compelling strategies for controlling contagious fungal diseases is a pressing issue in farming sector. Fungicide inquire about has furnished a wide scope of products with new methods of activity. Fungicides have significantly added to supporting quality nourishment generation through securing an assortment of harvests from contagious maladies. Be that as it may, such creation is frequently undermined by the event of pathogen strains resistant to fungicides. Broad utilization of these mixes in agriculture improves open nervousness because of the destructive potential for nature and human wellbeing. In addition, the phytotoxic impacts of certain fungicides are now perceived yet little is thought about their effect on the photosynthetic contraption and plant physiology. The advancement of resistance represents a progressing risk to the practices of disease management. Fungicide resistance gives a specific preferred benefit under assortment of fungicide; however, resistance-conferring mutations may also result in fitness penalties, resulting in an evolutionary trade-off/developmental exchange off. This review gives a comprehension of concept of fungicide resistance, broadness of action of fungicides in accordance to major classes of fungicides, instruments of activity of fungicides, the occurrence of phytotoxicity and an idea about the occurrence and mechanism of fungicide resistance. At last risk analysis study is carried out to assess risk of resistance development.

\section{Introduction}

Fungicides are categorized as chemical compounds deployed for plant fungal disease management. Fungicide implementation is now quite prevalent worldwide as fungicides have been the primary means of suppressing fungal pathogen due to their reasonable cost, convenience of use and efficacy. During the period of commercial use of a fungicide, populace of the target organism can arise that are no longer sufficiently responsive to be controlled competently. Fungicide resistance is generally classified as a phenomenon wherein the population of a pathogen under consideration modifies from being susceptible to a fungicide, to one that is insensitive or less responsive to a fungicide. This aspect has been perceived as 'insensitivity' or 'tolerance'. The former term 
is favoured, as fungicide resistance is easily confused with host-plant resistance to some species or pathotypes of fungi. Also, the term 'fungicide resistance' is known to be synonymous to another term called 'acquired resistance'. However, it is to be noted down that resistance may not always be complete.

When resistance is not absolute in a fungus, it may sometimes be referred to as having lessened response to a fungicide. Either sooner or later, resistance arise as a response to continuous use of the fungicide, or to repeated use of another fungicide which is associated to it chemically and/or biochemically via an analogous process of antifungal action. This appearance of resistant populations of target pathogens, which were earlier well managed, has been attributed for production of antibacterial drugs (e.g. sulphonamides, penicillin, and streptomycin) and for agricultural insecticides (e.g. DDT). Most of the prescribed treatments of fungicides are known to provide $90 \%$ or greater control of the target pathogen, and give the farmer a cost: benefit ratio of at least 1:3. Some diseases, e.g. apple scab caused by Venturia inaequalis necessitate an exceedingly high level of management. Many fungicides have applications against a broad assortment of diseases of fungal nature, while some possess a restricted range of action in opposition to a single or even two definite classes of plant pathogens. Regardless of the piece of evidence that many fungicides are commercialised, in accordance to a particular crop disease, it is known to be well controlled by only three or four different types of fungicide formulations, so that any decrease in efficacy of a formerly reliable fungicide via resistance development can pose to be a major threat in accordance to a grower and to a nation in one piece.

Specifically two categories of factors influence fungicide resistance: pathogenrelated factors and fungicide-related factors.
An illustration of a fungal pathogen-related factor (which can affect the threat of fungicide resistance) requires a degree of genetic variability with that pathogen populace. Fungal pathogens undergoing recombination within that population could have a higher level of genetic variability. In particular, resistance to fungicides is somewhat more probable to be established in populations of fungi with a high level of genetic variability relative to populations having little genetic variability. Resistance to fungicides particularly originates in fungi with a short time of generation. A faster generation time implies that in a growing season there will be more individual isolates of the fungus. This allows for greater genetic diversity and a greater likelihood of mutation that would lead to lower responsiveness to a fungicide. Fungi developing a hefty quantity of spores are also more prone to develop resistance to fungicides. Fungi which have identified several of these factors are those that would be considered at the greatest risk of occurrence of fungicide resistance.

The action site of the fungicide includes an illustration of a factor affiliated with the fungicide which can affect the threat of fungicide resistance. Fungicides with a particular site of operation have a greater chance of selecting strains of a fungus that are fungicide-resistant compared to fungicides having a criterion characterised by multi-sites. Factors correlated with a specific application of fungicides can trigger the threat of resistance to fungicides. Fungicides many of which are introduced over a given season are already at an elevated threat of developing resistance to fungi. If this fungicide is commonly used year in and year out within a region, the threat becomes that much higher. Fungicides usually administered after early symptoms that could be deemed a preventive form of application are more vulnerable to resistance to fungicides. Permitting an 
epidemic of a disease to be ongoing before applying a fungicide may enable the fungus to get into multiple cycles and be at an elevated population at the time of application of the fungicide. This, in effect, increases the likelihood of a fungicide-resistant mutant appearing. Fungicides not administered in confluence with varying fungicide active ingredients from different groups of fungicides are at heightened threat of occurrence of fungicide resistance.

In this review paper, we focus exclusively on examining fungicide groups used to monitor major plant pathogens and fungicide resistance evolution. Basically, we are investigating the basic resistance mechanisms to study its emergence in accordance to assessment of risk of fungicide resistance.

\section{Broadness of Action of Fungicides}

Contingent upon the extent of their objectives, fungicides can be named single-site or multi site. Fungicides acclimatized to single-site are dynamic in opposition to one point in a single metabolic pathway of fungi. Instances of most of these fungicides may include various drugs with sole dynamic component, for instance, benzimidazoles, prothioconazole and fludioxonil. Nonetheless, there are associations that are not entirely striking to utilize alone, for instance, azoxystrobin is prescribed to use as a blend with different fungicides having an alternate mode of activity (Jørgensen et al., 2018). The likelihood of the pathogen's advancement into resistance, for this situation, is fundamentally decreased on the grounds that resistance secludes/isolates to one fungicide will be eliminated by another fungicide. The adequacy of this strategy can be shown by fungicide such as Metalaxyl. At the point when utilized as the principal molecule in Ireland to battle contamination in potatoes (Phytophthora infestans) resistance evolved inside one developing season. Be that as it may, in nations, for example, the UK where it was sold distinctly as a blend, resistance issues grew all the more gradually (Vincelli and Munshaw, 2014). Then again, in light of this particular activity, fungus is bound to evolve to possess resistance against the action of fungicide. Multi-site fungicides can focus on numerous areas (distinctive metabolic pathways). However, single-site fungicides are viewed as less dangerous to plants. More established contact fungicides, for example, mancozeb and so forth have multi-site action and influence numerous species of fungi in various classes such as Alternaria, Peronospora, Botrytis, and Sclerotinia (Cameron, 2016). Because of the ascent in the stringency and number of regularizing tests required to enlist another dynamic ingredient, fungicide producers have thought that it was simpler to create single-site systemics as of late (McGrath, 2004). Thus, resistance to fungicide has become a progressively basic issue in disease guideline/regulation.

\section{Major classes of fungicides}

Baibakova et al., (2019) described five main classes of chemical fungicides as presented in Table 1. The biggest gathering of them is triazoles. Fungicides of this class are widely utilised. Triazoles likewise have phytotoxicity to ensured plants. In a critical sum, fungicides cause a retardant impact (debilitated amalgamation of gibberellins); abuse the union of sterols, lessen transpiration of plants (Allen, 2013). Substances/ingredients contrast in the level of movement, the pace of utilization, the range of consequences for pathogens, the evaluation of hazard to biological systems, the populace and working staff, the recompense of the expenses of their utilization. Regardless of the wide scope of activity, triazoles have impediments. Triadimenol and propiconazole defer the evacuation of the essential leaf and abuse its 
geotropism in the preparing of grain seeds. Tebuconazole can go into the retardant under ominous conditions (waterlogging, absence of dampness, low germination vitality, and so forth.). The orderly utilization or dependence on triazoles prompts the rise of fungal strains which are resistant. For instance, triadimefon doesn't totally restrain the contagious germination of Puccinia. The broadly acknowledged presumption that fungicide has low phytotoxicity has begun to be obsolete with the production of increasingly itemized examinations at the cell level that showed a few harms to the photosynthetic mechanical assembly (Petit et al., 2008; Saladin et al., 2003).

Strobilurin class incorporates synthetic/ engineered substances comparable in structure to characteristic fungicidal poisons/toxins strobilurin A and strobilurin B, isolated from Strobilurus tenacellus (Balba, 2007). Because of the wide scope of activities and down to earth security for the environment, strobilurins are viewed as the most noteworthy class of fungicides that showed up after the provision of the triazole classes. These substances can be ascribed to biofungicides as they are of normal beginning (Reddy, 2012). Strobilurins are prescribed to be utilized first in the developing season since they quickly decrease the capacity of imperviousness/resistance to triazole structures to their expansion on leaves. What's more, the selection parameter is diminished, since the degree of the inoculum is the most minimal toward the start of the developing season. Cases of development of resistance are enrolled in Botrytis cinerea, Erysiphe graminis, and Oidium erysiphoides (Leroux et al., 2000). Elevated protection/ resistance from/to strobilurins is because of a one-point change in an element of the cytochrome $b$ particle, which decides binding of this catalyst to fungicides. Simultaneously, the dynamic focal point of the enzyme doesn't change, and the resistant types of fungi don't lose their suitability because of transformation and the acquirement of resistance to strobilurins. To avoid resistance, just 1-2 applications (now and again, three) at interims of 14-16 days are allowed during the season and just planning in the fungicide shift framework with an alternate component of activity from strobilurins (Benelli, 2013) are permitted.

Subsidiaries of Benzimidazole class are compelling against ailments of vegetative organs, just as a complex of phytopathogens transmitted between seeds, so they find wide application as seed disinfectants (Cameron, 2016). A few reports show abatement in biomass generation as in case of Nicotiana tabacum, wherein the use of carbendazim (fundamental benzimidazole fungicide) resulted in having a negative impact on its biomass development and also in fungicidetreated plants: benomyl, a fundamental fungicide, decreased the development of Helianthus annuus, Pinus taeda, Gossypium hirsutum, Lactuca sativa and Cucumis sativus (Hunsche et al., 2007). The restricted selectivity of the activity adds to an adequately fast choice of safe genotypes and the development of a safe populace after a methodical (inside 3-4 years) utilization of substantive of this class of fungicide (García et al., 2003). Upon investigation of Mycosphaerella graminicola in France, negative cross-resistance from edifenphos and a few sterol biosynthesis inhibitors, for example, prochloraz and fenpropimorph, was seen in strains impervious to fenhexylamide (Leroux et al., 2000) was noted. This concept of cross-resistance is explained as fungal organisms that are impervious/ resistant to one fungicide are regularly additionally impervious/resistant to different fungicides from a similar concoction class. Now and then between fungicides from various substance classes, there is a negative cross-resistance and the explanation behind this marvel might 
be that hereditary adjustments that happens under the activity of a solitary fungicide and confers protection from it, causes the resistant isolate to confine progressively vulnerable to another fungicide (McGrath, 2004).

The following class of fungicides is phenylpyrrole. They are concoction analogs of the regular antifungal compound pyrrolnitrin (Kilani and Fillinger, 2016). As of now, fungicoxon is utilized as the dynamic substance of fungicides. Phenylsilyl restrains all phases of development of fungus, germination of spores, protracting of the embryonic cylinders and mycelium development. The watched results are swollen hyphae with expanded spreading and apical lysis, which demonstrate that phenylpyrls can follow up on the biosynthesis of the intragenic turgor and cell divider (Lew, 2010). To maintain a strategic distance from the development of resistance from phenylpyrroles, combined preparations ought to be utilized or exchange with various components of activity. Notwithstanding issues with conceivable resistance, there is a danger of phytotoxic impacts in connection to ensuring plants (Petit et al., 2008).

Utilization of such fungicides have ramifications for plant physiology, for example, a plant development decrease, irritation of regenerative organ advancement, modification of nitrogen, or potentially carbon digestion and point of confinement photosynthetic action (Petit et al.,2008; Leroux et al., 2000; Saladin et al.,2003).

Morpholines are a class of low-lethal and profoundly successful fungicides, one of the principal gatherings of sterol blend inhibitors. Albeit different inhibitors of sterol amalgamation outflank the gathering of morpholines by financial parameters, these substances again get significance for the issue of the resistance from fungicides (Lamberth,
2012). As opposed to triazoles, morpholines obstruct the isomerization and decrease responses during the time spent sterols biosynthesis, along these lines the populaces of parasites that are impervious to them are shaped substantially more gradually. As indicated by the range of activity on pathogens, morpholines don't vary from triazoles yet require higher application rates. Regardless of the moderate improvement of resistant strains, there is a potential for dimethomorph to create resistant strains of pathogens that don't have crossprotection/resistance from phenylamides.

\section{Emergence and Mechanism of Fungicide Resistance}

The occurrence of fungicide resistance was observed to enhance with the influx of the systemic fungicides, and the period it took for fungicide resistance to develop was proportionately short, sometimes the resistance was observed just within 24 months since their first commercial introduction. A number of the fungicides instigated from the time of 1960 are known to be unequivocally afflicted, with the striking exceptions of, phenylpyrroles, fosetyl-aluminium in addition to anilinopyrimidines, and some other fungicides used for the management of ailments like blast disease of rice (e.g., tricyclazole, isoprothiolane and probenazole), as these are acknowledged to maintain their efficacy even after a long duration and commercial use. Few of the recently introduced fungicides such as carboxylic acid amides and benzamides are not recorded to attribute to serious resistance problems, most probably due to precautions followed in the management practices. Also, many of the other fungicides, such as, sulphur fungicides, copper, chlorothalonil, phthalimides (e.g. captan) and dithiocarbamates (e.g. mancozeb), and, have maintained their full responsiveness, in defiance of their repeated and sometimes 
specific use for a long period of time. Most of the time, inception of resistance is accredited to total, or almost total, failure of disease management. A farmer's perception regarding abrupt loss of efficacy of a fungicide can be attributed to provide the very first attestation of fungicide resistance. In order to understand the emergence of resistance to fungicides in field populaces of pathogens, it is important to outline the mechanisms which bring about reduced sensitivity to the compound and also to the basis of genetics of the resistance trait. Hence, we are going to discuss the concept of Qualitative and quantitative fungicide resistance.

\section{Qualitative and quantitative fungicide resistance}

The mechanisms providing fungicide resistance, be that as it may, may contrast, and the expressions "qualitative resistance" and "quantitative resistance" have been instituted to demonstrate these distinctions (Fig. 1). Qualitative resistance is acknowledged to be change/ mutation based. Transformations/ Mutations might be induced by UV light, which is of specific significance in wind-borne uncolored spores. On the off chance that a gene encoding the objective protein is changed, with the goal that an amino acid required for binding of the fungicide is traded, hindrance of the protein does never again happen and fungicide applications come up short (Fig. 1A). For this situation, regardless of whether high fungicide doses are utilized, already resistant individuals are not influenced and endure the treatment. Ensuing uses of a similar fungicide continually select for mutants, so that in the long run the wildtype individuals vanish and the populace comprises of fungicide-resistant mutants as it were. During the selection procedure, just full sensitivity or complete resistance is seen at the level of individuals; phenotypes with intermediate resistance don't happen. Rate of the selection relies upon the inherent biology of the pathogen also on the quantity of fungicide applications. Mutation based fungicide resistance is inheritable, and the offspring can create within the sight of the specific fungicide. Curiously, frequently no huge loss of virulence happens in resistant populaces (Barr et al., 2005; Chen et al., 2007; Lesemann et al., 2006 and Sierotzki et al., 2000).

Quantitative resistance is interceded by maintenance of the intracellular fungicide concentration at low levels. Systems keeping the intracellular fungicide concentration underneath a basic threshold limit incorporate synthesis of efflux transporters that emit drug molecules to the extracellular space, modifications of plasma membrane causing decreased fungicide permeability, or by production of chemicals that debase fungicide particles. (Del Sorbo et al., 2000; Jabs et al., 2001 Loffler et al., 2000) Then again, overexpression of the gene encoding the fungicide target or usage of alternate metabolic pathways has been accounted for (Kontoyiannis et al., 1999; Miguez et al., 2004; Schnabel et al., 2001; Steinfeld et al., 2001; White et al., 2002 and Ziogas et al., 1997). All in all, populaces comprise of individuals with pretty much articulated degrees of resistance to fungicides which is because different mechanisms providing resilience are dynamic at various levels. In the event that fungicide treatments are carried out, the tolerant individuals are probably going to endure, and, what's more, sub-lethal fungicide stress will invigorate amalgamation of efflux transporters and drug-degrading catalysts and so on (Fig. 1B). As a result, rehashed fungicide treatments will move a fungal populace, and individuals with varying and after some time even increasing levels of resistance can be observed until in the long run the whole populace comprises of totally resistant individuals. Likewise, efflux 
transporters have been examined in some detail, and which currently demonstrates that these transporters speak of a significant mechanism of setting up quantitative resistance.

Development of fungicide resistance is a selection process, with the fungicide as the selecting agent. In qualitative resistance (Fig. 1A), mutation-based insensitive mutants are selected, and strains are either sensitive or resistant to the drug. In quantitative resistance (Fig. 1B) individuals that express genes leading to reduced fungicide sensitivity, are more likely to survive a drug treatment. Sublethal fungicide stress leads to further induction of genes that help resisting subsequent drug treatments. As a consequence the population is shifted to increasing resistance, and increasing numbers of individuals with higher degrees of resistance are found.

\section{Assessment of resistance risk}

Resistance is an occurrence which results from of natural selection, and the ability of pathogens to create resistant mutants is a key feature in risk assessment. This risk can be tended to by endeavors to produce resistant mutants in target pathogens, either by counterfeit mutagenesis following treatment of spores with concoction mutagens or U/V-light, or presenting progressive generations to expanding fungicide concentrations. Stable resistant mutants in hereditarily tractable pathogens give proof of whether obstruction is under single or numerous quality gene controls, which significantly impacts chance investigation/risk analysis. For instance, the liability of single-site fungicides to resistance advancement is a result of three distinct components: the fungicide method of activity and use, biology of pathogen and process of disease transmission. These criteria have been utilized in blend to evaluate the general risk of resistance happening in differentiating pathogens and development frameworks to various classes of chemicals (Kuck and Russell, 2006; Brent and Hollomon, 2007). This would require exact proportions of rates of mutations and populace size, extents of sensitive and insensitive individuals in the pathogen populace (van den Bosch and Gilligan, 2008), the selection/determination coefficient (the distinction in wellness between the resistant and the delicate strain because of use of the fungicide (van den Bosch et al., 2014)), just as different components impacting the survival and intrusion of strains which are resistant (Gubbins and Gilligan, 1999).

Levels of resistance that can cause loss of control are regularly connected to amino corrosive changes in a protein that influence authoritative binding of a fungicide to its objective target. Eventually, this must be affirmed by biochemical investigation of the association of the fungicide with filtered target protein. In the past this information has not emerged developed until a novel fungicide has been propelled financially. The risk appraisal/assessment recognizes some key qualities that are significant determinants of risk of resistance, including pathogen idle/latent periods every year, number of harvest species tainted by the pathogen, protected versus open field development framework, and fungicide molecular intricacy (with high-multifaceted nature particles displaying more prominent restricting explicitness to their objective target site, with a higher likelihood of little changes trading off viability).

A model consolidating such key qualities clarified $61 \%$ of the variation in time in years to development of resistance for single-site fungicides. It is likewise suggested that such quality based resistance risk evaluations could be utilized to foresee the potential resistance 
chance status of fungicides with novel methods of activity, when there is no earlier information on their conduct in down to earth use. Pathogen risk levels might be amended after some time dependent on reactions to new fungicide classes or changes in fungicide use. In general, the rust fungus have been viewed as at moderately okay of developing resistance to other fungicide classes, yet as of late this has been addressed (Oliver, 2014). Be that as it may, as of late a sub-atomic, imaging, and recombinant DNA procedures have been consolidated into risk investigation programs, and together with modelling of protein and crystallography, they can anticipate the effect of various amino acid change on the concept of resistance. Proof acquired along these lines can give the DNA arrangement information to create rapid molecular diagnostic procedures to screen the recurrence of transformations/ mutations in pathogen populaces.

At last, and maybe the most troublesome, advance in risk investigation includes deciding, ideally in a target/objective pathogen, the fitness impact of mutations. Estimations of contamination proficiency, sporulation, and development give a helpful manual for wellness, however in a perfect world these ought to be enlarged with antagonism tests including blends of resistant and delicate isolates so as to decide the relative wellness. The impact of resistant changes/mutations on the mechanism of target catalysts significantly adds to the estimations of any risk assessment. It is basic that any test of fitness is done under controlled conditions in the research facility or glasshouse, to guarantee that artifical mutants are not discharged into field crops

In conclusion, the utilization of fungicides has expected significance throughout the years in the control of all the more harming plant pathogens against which resistance isn't effectively accessible or is temperamental, especially for polycyclic pathogens. Fungicides are generally utilized and have become the fundamental methods for repressing the development of growths and parasitic spores because of their moderately minimal effort, high effectiveness and convenience. The new chemical compounds which have started from various methodologies, for example, conventional arbitrary screening and from normal items are relied upon to give better infection control alternatives and are environmentally protected show great viability at much lower portions. These require lesser applications per season contrasted with before mixes. Since they have novel methods of activity, there are fewer odds of resistance improvement or cross resistance to past fungicides. Be that as it may, in spite of the wide assortment of existing items and different courses of utilization, the issue of the rise of new fungicide-safe strains of pathogens stays open. Accessible investigations have exhibited that fungicide application may disable photosynthesis, the amalgamation of sterols, gibberellins, transpiration, diminish $\mathrm{CO}_{2}$ osmosis and biomass, effect on the substance of the all out color. These are likewise effectively degradable and present less risk to nature. There is huge improvement in their plans and are more secure to the yields. At times, the advantage increased through fungicide use is increasingly basic to the degree that specific harvests can't be developed without disease management that remaining parts vigorously subject to the utilization of fungicides. In any case, gives an account of phytotoxicity are commonly founded on a couple of physiological parameters utilizing an enormous assortment of plant species and various sorts and centralizations of fungicides, driving at times to conflicting outcomes. This essentially risks exhaustive information on the essential impacts of fungicides on the photosynthesis and surely merits further examination. Concentrated utilization of 
synthetic control measures has thusly prompted its very own difficulties, including resistance to fungicides. The feasible utilization of fungicides to drag out their adequacy and convenience to cultivators is critical, and the execution of obstruction the executives systems are fundamental piece of this. Just if the long haul adequacy of fungicides can be guaranteed will industry contribute the cash and assets required for their revelation and advancement, particularly thinking about the exclusive expectations of the present enrollment prerequisites. Besides, the issue of the negative effect of fungicides on nature because of their high lethality still stays uncertain. Notwithstanding, the circumstance can be improved with the utilization of new advances and a more profound comprehension of the fungicides component of activity.

Fig.1 Development of fungicide resistance (Deising et al., 2008)

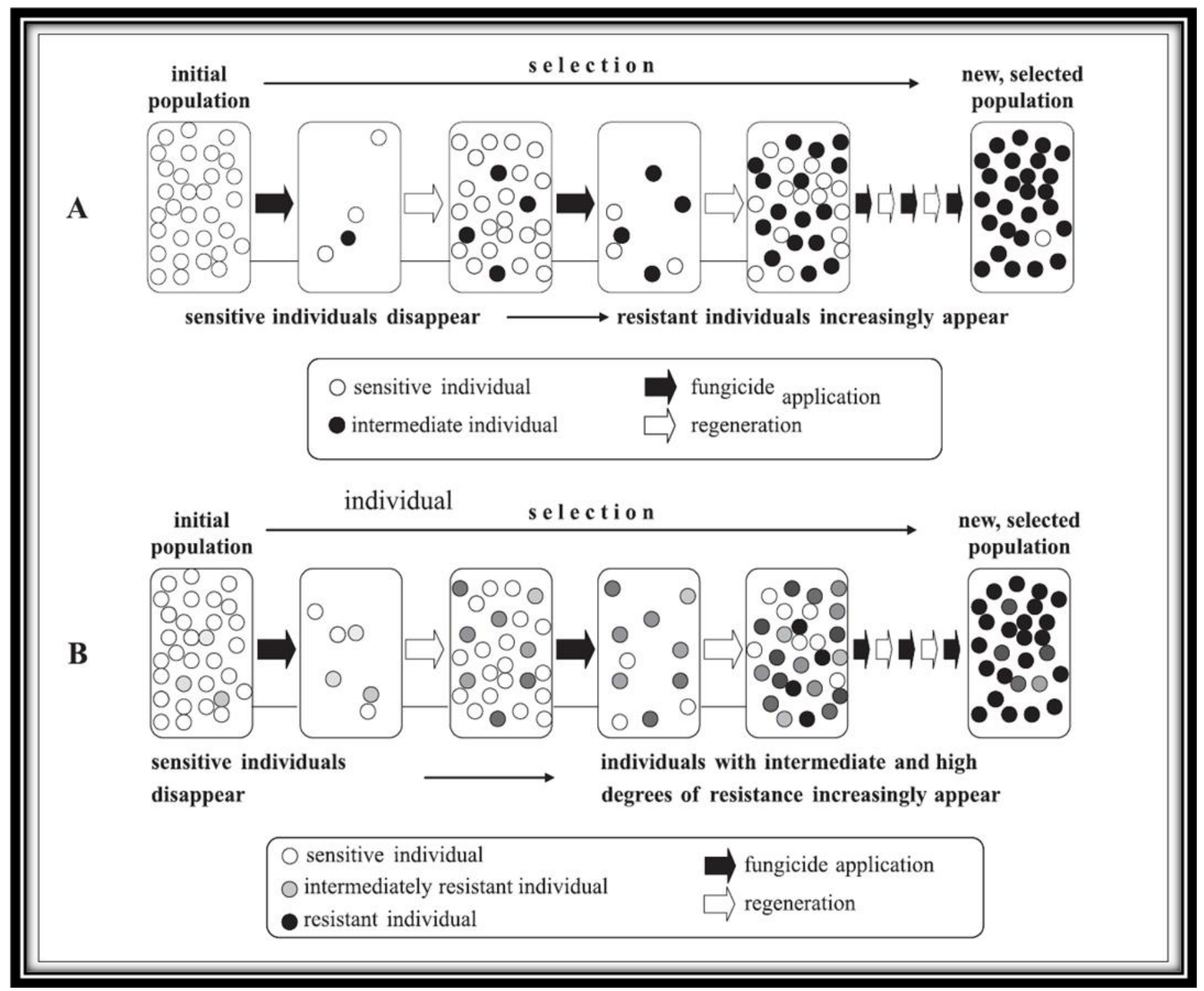


Table.1 Five Major chemical classes of fungicides along with their action mechanism as described by Baibakova et al., (2019)

\begin{tabular}{|c|c|c|c|c|c|}
\hline $\begin{array}{l}\text { CHEMICAL } \\
\text { CLASS }\end{array}$ & $\begin{array}{l}\text { INCLUSIVE } \\
\text { FUNGICIDES }\end{array}$ & $\begin{array}{c}\text { FUNGI } \\
\text { TARGETED }\end{array}$ & $\begin{array}{c}\text { ACTION } \\
\text { MECHANISM }\end{array}$ & $\begin{array}{c}\text { RESULTANT } \\
\text { PHYTOTOXICITY }\end{array}$ & $\begin{array}{l}\text { RESISTANCE } \\
\text { OBSERVED }\end{array}$ \\
\hline Triazoles & $\begin{array}{l}\text { propiconazol, } \\
\text { diniconazole, } \\
\text { ciproconazole, } \\
\text { flutriafol, } \\
\text { tebuconazole, } \\
\text { triadimefon, } \\
\text { epoxiconazole, } \\
\text { prothioconazole, } \\
\text { triticonazole, } \\
\text { diphenoconazole }\end{array}$ & $\begin{array}{c}\text { Botrytis, } \\
\text { Ustilago, } \\
\text { Cercospora, } \\
\text { Tilletia } \\
\text { Zymoseptoria, } \\
\text { Fusarium, } \\
\text { Cochliobolus, } \\
\text { Erysiphe, } \\
\text { Altemaria, } \\
\text { Puccinia, } \\
\text { Septoria, } \\
\text { Pythium, } \\
\text { Drechslera, } \\
\text { Pyrenophora, } \\
\text { Rhynchosporium, } \\
\text { Cladosporium, } \\
\text { Epicoccum, } \\
\text { Phoma }\end{array}$ & $\begin{array}{l}\text { Inhibit sterol } \\
\text { Biosynthesis }\end{array}$ & $\begin{array}{l}\text { There is a } \\
\text { violation of the } \\
\text { synthesis of } \\
\text { gibberellins } \\
\text { (retardant effect), } \\
\text { the synthesis of } \\
\text { sterols, a } \\
\text { decrease in } \\
\text { transpiration of } \\
\text { plants }\end{array}$ & $\begin{array}{l}\text { The systematic } \\
\text { use of } \\
\text { drugs based on } \\
\text { triazoles causes } \\
\text { resistance. The } \\
\text { triadimefon does } \\
\text { not } \\
\text { completely inhibit } \\
\text { the } \\
\text { germination of } \\
\text { conidia } \\
\text { and rust } \\
\text { urediospores. }\end{array}$ \\
\hline Strobilurins & $\begin{array}{l}\text { Picoxystrobin, } \\
\text { fluoxastrobin, } \\
\text { azoxystrobin, } \\
\text { trifloxystrobin, } \\
\text { pyraclostrobin, } \\
\text { krezoksim- } \\
\text { methyl }\end{array}$ & $\begin{array}{c}\text { Puccinia, } \\
\text { Septoria, } \\
\text { Pyrenophora, } \\
\text { Alternaria, } \\
\text { Cladosporium, } \\
\text { Epicoccum, } \\
\text { Botrytis, } \\
\text { Rhynchosporium, } \\
\text { Drechslera, } \\
\text { Fusarium, } \\
\text { Rhizoctonia, } \\
\text { Ustilago, } \\
\text { Erysiphe }\end{array}$ & $\begin{array}{l}\text { Inhibit } \\
\text { mitochondrial } \\
\text { respiration by } \\
\text { blocking } \\
\text { electron } \\
\text { transport in the } \\
\text { cytochrome b } \\
\text { and } \\
\text { c1 chain }\end{array}$ & $\begin{array}{l}\text { In the plant are } \\
\text { rapidly hydrolyzed } \\
\text { by ether linkage. } \\
\text { During periods of } \\
\text { drought, damage } \\
\text { is exacerbated }\end{array}$ & $\begin{array}{c}\text { Field resistance } \\
\text { was } \\
\text { recorded in } \\
\text { Oidium } \\
\text { erysiphoides, } \\
\text { Erysiphe } \\
\text { graminis, Botrytis } \\
\text { cineria. When } \\
\text { strobilurins } \\
\text { inhibit the } \\
\text { activity of } \\
\text { cytochrome } \\
\text { b, alternative } \\
\text { pathways } \\
\text { of electron } \\
\text { transport } \\
\text { can easily be } \\
\text { activated }\end{array}$ \\
\hline Benzimidazoles & $\begin{array}{l}\text { Prochloraz, } \\
\text { thiabendazole, } \\
\text { thiophanate- } \\
\text { methyl, } \\
\text { benomyl, }\end{array}$ & $\begin{array}{l}\text { Fusarium, } \\
\text { Botrytis, } \\
\text { Sclerotmia, } \\
\text { Septoria, } \\
\text { Uncinula, }\end{array}$ & $\begin{array}{l}\text { Inhibit the } \\
\text { synthesis of } \\
\text { ergosterol in the } \\
\text { fungal cell and } \\
\text { disrupt its life }\end{array}$ & $\begin{array}{l}\text { Decrease plant } \\
\text { biomass. induces } \\
\text { a considerable } \\
\text { reduction on the } \\
\text { chlorophyll a, }\end{array}$ & $\begin{array}{l}\text { Stable pathogenic } \\
\text { strains: } \\
\text { Pseudocerco- } \\
\text { sporella, } \\
\text { Septoria, }\end{array}$ \\
\hline
\end{tabular}




\begin{tabular}{|c|c|c|c|c|c|}
\hline & carbendazim & Erysiphe & activity & $\begin{array}{l}\text { chlorophyll b, } \\
\text { carotenoids, and } \\
\text { the total pigments } \\
\text { content }\end{array}$ & $\begin{array}{l}\text { Fusarium, } \\
\text { Erysipe, }\end{array}$ \\
\hline Phenylpyrroles & Fluodioxonyl & $\begin{array}{l}\text { Tilletia, Fusarium, } \\
\text { Ascochyta, } \\
\text { Altemaria, } \\
\text { Fusarium, } \\
\text { Aspergillus, } \\
\text { Rhizoctonia } \\
\text { Helminthosporium, }\end{array}$ & $\begin{array}{l}\text { Inhibit micellic } \\
\text { growth, reduce } \\
\text { glucose } \\
\text { phosphorylation } \\
\text { during cell } \\
\text { respiration, } \\
\text { disrupt } \\
\text { the function of } \\
\text { cell } \\
\text { membranes }\end{array}$ & $\begin{array}{l}\text { Decrease } \mathrm{CO}_{2} \\
\text { assimilation, } \\
\text { transpiration, } \\
\text { stomatal } \\
\text { conductance and } \\
\text { intercellular } \mathrm{CO}_{2} \\
\text { concentration }\end{array}$ & $\begin{array}{l}\text { Low risk of } \\
\text { resistance } \\
\text { due to the } \\
\text { mechanism } \\
\text { of action }\end{array}$ \\
\hline $\begin{array}{l}\text { Morpholines } \\
\text { (cinnamic acid } \\
\text { derivatives) }\end{array}$ & $\begin{array}{l}\text { Spiroxamine, } \\
\text { dimethomorph }\end{array}$ & $\begin{array}{l}\text { Erysiphe, } \\
\text { Uncinula, } \\
\text { Septoria, } \\
\text { Puccinia }\end{array}$ & $\begin{array}{l}\text { Prevent the } \\
\text { formation of } \\
\text { mycelium and } \\
\text { block the } \\
\text { reduction } \\
\text { of the double } \\
\text { compound C-C } \\
\text { and ergosterol } \\
\text { synthesis } \\
\text { Erysiphe, } \\
\text { Uncinula, }\end{array}$ & $\begin{array}{l}\text { Decrease of the } \\
\text { sterols synthesis }\end{array}$ & $\begin{array}{l}\text { Stable fungal } \\
\text { strains } \\
\text { form slowly, } \\
\text { fungicides } \\
\text { block the } \\
\text { reduction } \\
\text { reactions in the } \\
\text { process of sterol } \\
\text { biosynthesis and } \\
\text { isomerization }\end{array}$ \\
\hline
\end{tabular}

\section{References}

Allen, T. 2013. Not everything is as it seems: Fungicide phytotoxicity and plant diseases| Mississippi Crop Situation. Mississippi Crop Situation Available:http://www.mississippicrops .com/2013/08/09/not-everything-isasit-seems fungicide-phytotoxicityandplant- diseases

Baibakova, E.V., Nefedjeva, E.E., SuskaMalawska, M., Wilk, M., Sevriukova, G.A. and Zheltobriukhov, V.F. 2019. Modern Fungicides: Mechanisms of Action, Fungal Resistance and Phytotoxic Effects. Annual Research and Review in Biology 32 (3): 1-16

Balba, H. 2007. Review of strobilurin fungicide chemicals. Journal of Environmental Science and Health,
Part B. 42(4):441-451. DOI: 10.1080/03601230701316465

Barr, C.M., Neiman, M. and Taylor, D.R. 2005. Inheritance and recombination of mitochondrial genomes in plants, fungi, and animals. New Phytologist 168: $39-50$

Benelli, J.J. 2013. Non-target effects of strobilurin fungicide applications on creeping bentgrass putting greens during summer stress

Brent, K. J., and Hollomon, D. W. 2007. Fungicide resistance: The assessment of risk. Brussels: CropLife International

Cameron, J. 2016. Effects of Seed Applied Fungicide on arbuscular mycorrhizal colonization of South Dakota cultivars of Oat, Soybean, and Corn

Chen, C., Wang, J., Luo, Q., Yuan, S. and 
Zhou, M. 2007. Characterization and fitness of carbendazim-resistant strains of Fusarium graminearum (wheat scab). Pest Management Science 63: 1201-1207

Deising, H.B., Reimann S. and Pascholati, S.F. 2008. Mechanisms and significance of fungicide resistance. Brazilian Journal of Microbiology 39:286-295

Del Sorbo, G., Schoonbeck, H. and De Waard, M.A. 2000. Fungal transporters involved in efflux of natural toxic compounds and fungicides. Fungal Genetics and Biology 30: 1-15

García, P.C., Rivero, R.M. and Ruiz J.M. 2003. The role of fungicides in the physiology of higher plants: Implications for defense responses 69(2):162-172.

Gubbins, S., and Gilligan, C. A. 1999. Invasion thresholds for fungicide resistance: deterministic and stochastic analyses. Proceedings of the Royal Society B-Biological Sciences 266(1437), 2539-2549

Hunsche, M., Damerow, L., Schmitz-Eiberger, M. and Noga, G. 2007. Mancozeb wash-off from apple seedlings by simulated rainfall as affected by drying time of fungicide deposit and rain characteristics. Crop Protection 26(5):768-774.

DOI: 10.1016/j.cropro.2006.07.003

Jabs, T., Cronshaw, K. and Freund, A. 2001. New strobilurin resistance mechanism in apple scab (Venturia inaequalis). Mitt. Deutsch. Phytomed. Ges. 31: 1516

Jørgensen, L.P., Oliver R.P. and Heick, T.M. 2018. Occurrence and avoidance of fungicide resistance in cereal diseases. 10.19103/AS.2018.0039.13 pp. 235259

Kilani, J. and Fillinger, S. 2016. Phenylpyrroles: 30 Years, Two
Molecules and (Nearly) No Resistance. Frontiers in Microbiology 7:2014. DOI: 10.3389/fmicb.2016.02014

Kontoyiannis, D.P., Sagar, N. and Hirschi, K.D. 1999. Overexpression of Erg11p by the regulatable GAL1 promoter confers fluconazole resistance in Saccharomyces cerevisiae. Antimicrob. Agents Chemother., 43: 2798-2800

Kuck, K. H., and Russell, P. E. 2006. FRAC: combined resistance risk assessment. Aspects of Applied Biology 78, 3-10

Lamberth, C. 2012. Morpholine fungicides for the treatment of powdery mildew. In: Bioactive Heterocyclic Compound Classes. Weinheim, Germany: Wiley$\mathrm{VCH}$ Verlag $\mathrm{GmbH}$ and Co. KGaA 119-127

Leroux, P., Chapeland, F., Arnold, A. and Gredt, M. 2000. New cases of negative cross-resistance between fungicides, including sterol biosynthesis inhibitors. Journal of General Plant Pathology 66(1):75-81.

DOI: 10.1007/PL00012925

Lesemann, S.S., Schimpke, S., Dunemann, F. and Deising, H.B. 2006. Mitochondrial heteroplasmy for the cytochrome $b$ gene controls the level of strobilurin resistance in the apple powdery mildew fungus Podosphaera leucotricha (Ell. and Ev.) E.S. Salmon. Journal of Plant Diseases and Protection 113: 259-266

Lew, R.R. 2010. Turgor and net ion flux responses to activation of the osmotic MAP kinase cascade by fludioxonil in the filamentous fungus Neurospora crassa. Fungal Genetics and Biology 47(8):721- $726 . \quad$ DOI: 10.1016/J.FGB.2010.05.007

Löffler, J., Einsele, H., Hebart, H., Schumacher, U., Hrastnik, C. and Daum, G. 2000. Phospholipid and sterol analysis of plasma membranes 
of azole-resistant Candida albicans strains. FEMS Microbiol. Lett., 185: 59-63.

McGrath, MT. 2004. What are Fungicides? The Plant Health Instructor DOI: 10.1094/PHI-I-2004-0825-01

Miguez, M., Reeve, C., Wood, P.M. and Hollomon, D.W. 2004. Alternative oxidase reduces the sensitivity of Mycospherella graminicola to QOI fungicides. Pest Manag. Sci. 60: 3-7

Oliver, R. 2014. A reassessment of the risk of rust fungi developing resistance to fungicides. Pest Management Science 70(11), 1641-1645. http://dx.doi.org/10.1002/ps.3767.

Petit, A.N., Fontaine, F., Clement, C., and Vaillant-Gaveau N. 2008. Photosynthesis limitations of grapevine after treatment with the fungicide fludioxonil. Agriculture and Food Chemistry 56:6761-6767. DOI: $10.1021 / \mathrm{jf} 800919 \mathrm{u}$

Reddy, P.P. 2012. Strobilurin Fungicides. In: Recent advances in crop protection. New Delhi: Springer India. 185-200

Saladin, G., Magné, C.C. and Clément, C. 2003. Effects of fludioxonil and pyrimethanil, two fungicides used against Botrytis cinerea, on carbohydrate physiology in Vitis vinifera L. Pest Management Science 59(10):1083-1092.

DOI: $10.1002 / \mathrm{ps} .733$

Schnabel, G. and Jones, A.L. 2001. The 14 $\alpha-$ demethylase (CYP51A1) gene is overexpressed in Venturia inaequalis strains resistant to myclobutanil.
Phytopathology 91: 102-110

Sierotzki, H., Wullschleger, J. and Gisi, U. 2000. Point mutation in cytochrome $b$ gene conferring resistance to strobilurin fungicides in Erysiphe graminis f. sp. tritici field isolates. Pesticide Biochemistry and Physiology 68: 107-112

Steinfeld, U., Sierotzki, H., Parisi, S., Poirey, S. and Gisi, U. 2001. Sensitivity of mitochondrial respiration to different inhibitors in Venturia inaequalis. Pest Manag. Sci., 57: 787-796

van den Bosch, F., and Gilligan, C. A. 2008. Models of fungicide resistance dynamics. Annual Review of Phytopathology 46, 123-147

van den Bosch, F., Oliver, R., van den Berg, F., and Paveley, N. 2014. Governing principles can guide fungicide resistance management tactics. Annual Review of Phytopathology 52, 175195.

http://dx.doi.org/10.1146/annurevphyto-102313-050158

Vincelli, P. and Munshaw, G. 2014. Chemical Control of Turfgrass Diseases.

White, T.C., Holleman, S., Dy, F., Mirels, L.F. and Stevens, D.A. 2002. Resistance mechanisms in clinical isolates of Candida albicans. Antimicrob. Agents Chemother., 46: 1704-1713

Ziogas, B.N., Baldwin, B.C. and Young, J.E. 1997. Alternative respiration: a biochemical mechanism of resistance to azoxistrobin (ICIA 5504) in Septoria tritici. Pest. Sci., 50: 28-34.

\section{How to cite this article:}

Rajat Sharma. 2019. Analytical Concept of Fungicide Resistance: A Review. Int.J.Curr.Microbiol.App.Sci. 8(12): 1672-1684. doi: https://doi.org/10.20546/ijcmas.2019.812.201 